\title{
Defining "Ministerial Aid": Union Decertification Under the National Labor Relations Act
}

\author{
Catherine Meeker †
}

The National Labor Relations Act ("NLRA") gives employees the right to select their union representatives. For a variety of reasons, however, unionized employees sometimes become dissatisfied with the representation their incumbent union provides them. The NLRA permits employees to petition to remove their incumbent union through a process called "decertification."

Unfortunately, few employees know about decertification; fewer still know how to start the process. Moreover, union representatives, who normally would offer employees guidance about their rights under federal labor law, have no incentive to help employees with decertification. And, while employers might be willing to help, the National Labor Relations Board ("NLRB" or "Board") has interpreted the NLRA to forbid any aid except "ministerial aid" from the employer. The prohibition against substantial employer aid imposes strict limits on the employer's actions, and yet the legal standards used to apply the prohibition are uncertain and vague. This uncertainty harms the interests of employees in two ways. First, employers may be reluctant to provide even legitimate assistance to employees seeking to decertify their union. Second, when employers do help, the NLRB often overturns the employees' decision to decertify because, in its judgment, the employer provided too much assistance, whether through actions that alone were "more than ministerial" or through a combination of too many trivial acts of assistance. Because most cases have involved more than one form of assistance, and the Board and reviewing courts have considered the actions only in combination, the decisions provide little guidance as to whether an individual act is permissible or how many permissible acts together become impermissible.

$\dagger$ B.A. 1996, Ball State University; J.D. 1999, The University of Chicago.

3 The National Labor Relations Act is codified at 29 USC $\$ 151-69$ (1994). Common references to "sections" of the Act correspond to the Act's codification. For example, Section 7 is codified at 29 USC $\S 157$, Section 8 is codified at 29 USC $\S 158$, and Section 10 is codified at 29 USC $\$ 160$. 
This Comment considers the standards that the NLRB and the courts have used to determine what sort of employer aid in decertification is legal under the NLRA and proposes that the NLRB and reviewing courts categorize individual employer actions as either "trivial" or "nontrivial." Part I explains the decertification process. Part II analyzes the Board's decisions in decertification cases to determine how it defines what acts of assistance employers can offer. This Part then examines the costs of the uncertainty produced by the Board's current ad hoc approach. Finally, Part III evaluates various standards that the Board and reviewing courts have used when addressing allegations that an employer improperly influenced a decertification decision. Part III concludes that the Board should adopt a prohibition on all nontrivial assistance whenever rendered. Because the NLRB has historically refused to issue rules, ${ }^{2}$ opting instead to adjudicate each case individually, this standard would likely be developed through Board and court decisions reviewing employer assistance. Even within the adjudicative process, however, the proposed standard will force the Board and courts to classify employer assistance more clearly, thereby reducing the existing uncertainty in this area.

\section{THE DECERTIFICATION PROCESS}

Section 7 of the NLRA, which grants employees in a bargaining unit the right to choose a union as their bargaining representative, also grants employees the freedom to reject union representation and generally to abstain from union activities. ${ }^{3}$ For an employer in any way to "interfere with, restrain or coerce employees" in the exercise of this choice is an unfair labor practice. ${ }^{4}$ As a corollary of the employees' freedom to choose a union,

2 See note 20 and accompanying text.

3 Section 7 provides:

Employees shall have the right to self-organization, to form, join, or assist labor organizations, to bargain collectively through representatives of their own choosing, and to engage in other concerted activities for the purpose of collective bargaining or other mutual aid or protection, and shall also have the right to refrain from any or all of such activities except to the extent that such right may be affected by an agreement requiring membership in a labor organization as a condition of employment as authorized in Section $8(a)(3)$.

29 USC $\S 157$ (emphasis added). Section 9(b) discusses the term "bargaining unit." 29 USC $\S 159(\mathrm{~b})$.

4 29 USC § 158(a)(1). Complaints of unfair labor practices, listed in Section 8, form the basis for Board prosecutions and decisions, the procedures for which are given in Section 10 . 
the Act also grants employees the qualified right to oust an incumbent union through decertification. ${ }^{5}$

As the structure of labor-management relations has changed, ${ }^{6}$ and union influence has declined over the last four decades, ${ }^{7}$ employees have used decertification petitions with increasing frequency and success. In 1965, only 200 decertification elections were held, 64 percent of which the unions lost. ${ }^{8}$ By contrast, between 1987 and 1991, an average of 636 decertification elections were held each year, resulting in an average union loss

s The requirements for decertification are (1) at least a year must have passed since the employees elected or the employer recognized the union, and (2) there must not be a collective bargaining agreement in effect (though employees may file a decertification petition in a brief window between 90 and 60 days before the expiration of the collective bargaining agreement in most industries and between 120 and 90 days in the case of a health care institution). Section 9(c)(3), 29 USC § 159(c)(3); General Cable Corp, 139 NLRB 1123, 1124-25 (1962) (stating the "contract bar" rule). Section $9(c)(1)$, which regulates action on petitions to the NLRB, provides:

Whenever a petition shall have been filed, in accordance with such regulations as may be prescribed by the Board-(A) by an employee or group of employees or any individual or labor organization acting in their behalf alleging that a substantial number of employees ... (ii) assert that the individual or labor organization, which has been certified or is being currently recognized by their employer as the bargaining representative, is no longer a representative as defined in Section 9(a) ... the Board shall investigate such petition and if it has reasonable cause to believe that a question of representation affecting commerce exists shall provide for an appropriate hearing upon due notice. . . . If the Board finds upon the record of such hearing that such a question of representation exists, it shall direct an election by secret ballot and shall certify the results thereof.

29 USC \& 159(c)(1). Also, even while a collective bargaining agreement is in effect, an employee-initiated petition for decertification signed by the majority of the employees may oust the union. While invalid as a means of directly removing the union, the petition may be used by the employer as evidence that he has a good faith doubt of the union's continuing majority status that justifies his withdrawal of recognition for the negotiation of future agreements. Indeed, the employer may stop bargaining even before a petition is filed or granted if he has a reasonable belief that a majority of the workers no longer wish to be represented by the union. See Vic Koenig Cheurolet, Inc $v$ NLRB, 126 F3d 947, 948 (7th Cir 1997); Rock-Tenn Co v NLRB, 69 F3d 803, 808 (7th Cir 1995).

- See Samuel Estreicher, Employer Involvement and the "Company Union" Prohibition: The Case for Partial Repeal of the Section 8(a)(2) of the NLRA, 69 NYU L Rev 125, 126-27 (1994) (noting the "transformed American workplace in which employers increasingly expect front-line workers to take on some of the functions previously performed by supervisors and engineers-where 'brain work' is no longer a sphere distinct from the tasks of operators, technicians, and maintenance personnel"); Michael H. LeRoy, Employer Domination of Labor Organizations and the Electromation Case: An Empirical Public Policy Analysis, 61 Geo Wash L Rev 1812, 1812-13 \& nn 75-78 (1993) (referring to and later substantiating the "coincidence of employer empowerment of employees and declining unionization" (citations omitted)).

7 Unions represented 35.7 percent of the workforce in the private sector in 1953; in 1992, they represented only 12.7 percent. Estreicher, 69 NYU L Rev at 133 \& n 27 (cited in note 6).

B Thirtieth Annual Report of the NLRB Table 13 (GPO 1965). 
rate of 72 percent. $^{9}$ The 1996 numbers, while lower, are still striking: 485 decertification elections were held and the union was ousted in 69 percent of those elections. ${ }^{10}$

The decertification procedure seems simple. At least 30 percent of the represented employees must sign either a petition or individual cards asserting that they no longer want to be represented by the union. They must file this petition with the NLRB. The NLRB verifies the veracity and validity of the petition and schedules an election; if the union receives 50 percent or less of the votes, decertification is complete. ${ }^{11}$

Not surprisingly, the union has little interest in ensuring that employees know of the decertification option and even less interest in answering questions about the NLRB process. ${ }^{12}$ The employer, on the other hand, may be quite willing to assist. Section $8(a)(1)$ of the NLRA, however, bars him from "interfer[ing] with, coerc[ing] or restrain[ing]"13 his employees in exercising their Section 7 right $^{14}$ to decide whether to retain the union; such actions constitute an unfair labor practice.

Just what this prohibition means in the context of decertification assistance is unclear. ${ }^{15}$ The Seventh Circuit has observed that "[t]he [NLRA] forbids the employer to interfere with the

- Fifty-Sixth Annual Report of the NLRB Table 13 (GPO 1991); Fifty-Fifth Annual Report of the NLRB Table 13 (GPO 1990); Fifty-Fourth Annual Report of the NLRB Table 13 (GPO 1989); Fifty-Thind Annual Report of the NLRB Table 13 (GPO 1988); Fifty-Second Annual Report of the NLRB Table 13 (GPO 1987).

${ }^{10}$ Sixty-First Annual Report of the NLRB Tables 10, 13 (GPO 1996). A total of $984 \mathrm{em}$ ployee petitions were filed, but 49.8 percent of them were withdrawn by the petitioners or dismissed, most of them before a hearing occurred.

"See 29 USC § 159.

${ }^{12}$ A commentator noted:

Most employees are unfamiliar with the process of disenfranchising themselves from a union. Unlike the total involvement of a union's representatives during the certification campaign, an incumbent union is clearly unwilling to provide assistance to disgruntled employees interested in expelling it. Employees are not generally familiar with the availability of regional offices of the NLRB and typically will seek advice from their employer concerning the removal of an incumbent union.

Ellen Rust Peirce, Employer Participation in the Decertification Process: How Big a Helping Hand?, 31 Buff L Rev 737, 750-51 (1983). See also William A. Krupman and Gregory I. Rasin, Decertification: Removing the Shroud, 30 Labor L J 231, 233 (1979) ("Certainly an incumbent union will not provide disgruntled employees with any assistance. In fact, Board decisions have upheld union expulsion of members who initiate decertification proceedings."); Douglas Ray, Industrial Stability and Decertification Elections: Need for Reform, 1984 Ariz St L J 257, 259 (arguing that employees should be comprehensively advised of their decertification rights, perhaps by the NLRB, to avoid this problem).

${ }^{13} 29$ USC $\$ 158(\mathrm{a})(1)$.

"See note 3 .

${ }^{15}$ The NLRB has decided that Section $8(a)(1)$ bars employers from spontaneously suggesting that employees decertify their union. See Peirce, 31 Buff $L$ Rev at 743-48 (cited in note 12) (discussing cases that establish this proposition). 
workers' choice, but is silent on whether, if some or all of the workers want to abandon collective bargaining, he may help them do so." ${ }^{\text {16 }}$ According to the NLRA, employees should exercise free choice in selecting or rejecting their representatives without interference from their employer. Labor market realities complicate this principle, however, as the employer may be the only one who can provide the necessary assistance. For example, even if employees have talked to the NLRB, they may still have difficulty understanding how to complete the Board's relatively complex decertification form or they may need someone to type their petition or provide them a ride to the nearest NLRB office to drop off the petition. ${ }^{17}$ Employees know they cannot turn to their union stewards, who normally represent the union in the bargaining unit, for assistance, and they may be unable or unwilling to hire their own attorneys; therefore, most employees eventually seek assistance from their employers. Thus, the Board must walk a fine line to prevent employers from violating Section $8(a)(1)$ by interfering with or coercing employees' choice without penalizing employers for assisting employees who are, in fact, exercising their free choice. Further complicating this situation is that the decisions, although made by an Administrative Law Judge ("ALJ"), can be easily appealed by either of the parties or the Board itself by filing an exception to the decision. Once exceptions to an ALJ report are filed, the Board is free to substitute its own findings and order for those of the ALJ. The Board's only constraints are that it must rely on the record presented to the ALJ and that Section 10 requires Board findings to be based on a preponderance of the evidence. ${ }^{18}$ Courts in turn review the Board's decisions using a reasonableness standard. ${ }^{19}$

Both courts and commentators have criticized the NLRB for its "stubbornly persisted-in reluctance to use its express rulemaking power"20 to give employers needed guidance in this area.

\footnotetext{
${ }^{18}$ Koenig, 126 F3d at 948 (citation omitted).

17 See Part II.

"s See 29 USC $\$ 160$.

"See note 31 for discussion of the standard of judicial review.

${ }^{20}$ Koenig, 126 F3d at 949-50. The Supreme Court recently noted, "The [NLRB], uniquely among major federal administrative agencies, has chosen to promulgate virtually all the legal rules in its field through adjudication rather than rulemaking. ... [O]nly one regulation has ever been adopted by the Board." Allentown Mack Sales and Service, Inc $v$ $N L R B, 522$ US $359,118 \mathrm{~S}$ Ct 818,827 (1998). This choice has been the object of both comment and criticism. See, for example, Mark H. Grunewald, The NLRB's First Rulemaking: An Exercise in Pragmatism, 41 Duke L J 274, 290-94 (1991) (discussing the underlying reasons and benefits of the 1989 NLRB experiment with rulemaking); Charles J. Morris, The NLRB in the Dog House-Can an Old Board Learn New Tricks?, 24 San Diego L Rev 9, 27-42 (1987) (arguing that the NLRB should effectuate a gradual change to rule-
} 
Instead, the Board relies solely on adjudicating individual cases to establish standards. Unfortunately, the Board's decisions as a group are so unclear and contradictory that the Board often disagrees with the findings of its own ALJs as to whether particular forms of employer assistance to employees seeking decertification constitute unfair labor practices. ${ }^{21}$ Given that decertification efforts are frequent, that employees are likely to seek employer assistance, and that the NLRB has broad remedial powers to correct employer violations in the decertification context (ranging from invalidating election results to reinstating the union and compelling the employer to bargain with the union if his assistance amounted to an unfair labor practice), ${ }^{22}$ it is easy to understand why the uncertain standard troubles employers. It provides them with little guidance as to what aid is appropriate and what aid is not.

making for reasons such as economic efficiency and easier dissemination of information to employees); Samuel Estreicher, Policy Oscillation at the Labor Board: A Plea for Rulemaking, 37 Admin L Rev 163, 175-77 (1985) (arguing the NLRB should use rulemaking because it will result in better reasoned, more legitimate, and more consistent policy). In justifying its behavior to the Supreme Court in a 1969 brief, the NLRB explained that formal rulemaking procedures are not sufficiently flexible to work effectively in the complex and changing areas the NLRB oversees. See Burton B. Subrin, Conserving Energy at the Labor Board: The Case for Making Rules on Collective Bargaining Units, 32 Lab L J 105, 111-12 (1981). Others have speculated that by legislating through adjudication, never presenting a clear and precise statement of policy, the NLRB "is able to minimize congressional and judicial intervention in its policies." Robert L. Willmore, Note, NLRB Rulemaking: Political Reality Versus Procedural Fairness, 89 Yale L J 982, 987-88, 993-98 (1980).

${ }^{21}$ There are numerous examples of Board decisions that disagree with the ALJ's view of the facts. See, for example, Pic Way Shoe Mart, 308 NLRB 84, 84 (1992) (finding employer's providing employee's name and phone number to a labor consultant to be a violation where ALJ had found it mere "ministerial aid" and thus no violation); Eastern States Optical Co, 275 NLRB 371, 371 (1985) (finding assistance in preparation of petition was ministerial aid where ALJ found violations); Placke Toyota, Inc, 215 NLRB 395, 395 (1974) (finding typing of petition and connotation of approval constituted violation where ALJ had recommended dismissal).

${ }^{22}$ Board elections are set aside and "rerun" when employer actions are deemed simply to have "tainted" the results. If an employer has tainted results, he may not rely on them to question the union's continuing majority status and withdraw recognition. This practice derives from the Board's "laboratory conditions" doctrine, established in General Shoe Corp, 77 NLRB 124, 127 (1948) (establishing that all elections must be free from employer interference, in order to determine the "uninhibited desires of the employees").

NLRB remedial authority for unfair labor practices derives from Section 10(c), which provides for a cease and desist order and "such affirmative action ... as will effectuate the policies of this Act." 29 USC § 160(c). In Caterair International, the Board "reaffirmed its longstanding policy that an affirmative bargaining order is the standard remedy to restore the status quo" after an employer unlawfully withdraws recognition from an incumbent union and subsequently refuses to bargain. 322 NLRB 64, 66-67 (1996), on remand from 22 F3d 1114, 1123 (DC Cir 1994). See also Sixty-First Annual Report at 59 (cited in note 10). 


\section{Existing Decisions Produce an Uncertain Standard}

\section{A. The Current Standard: "More Than Ministerial Aid"}

The NLRB most often applies a "more than ministerial aid" standard to decide whether an employer's assistance to an employee decertification effort is harmless or constitutes an unfair labor practice sufficient to derail decertification. ${ }^{23}$ Unfortunately for both employers and reviewing courts, "more than ministerial aid" is a malleable standard that eludes precise definition even when the Board applies it. To make matters more confusing, the Board uses different tests to determine when the standard has been met. It has at times phrased this standard in terms of whether "but for" the company's assistance the decertification would have occurred, whether the employer "substantially contributed" to the decertification effort, and whether the employer provided "more than minimal support and approval"-sometimes all in a single case. ${ }^{24}$ And in Royal Himmel Distilling $\mathrm{Co}^{25}$ the Board intimated that an employer might lawfully provide any assistance once its employees had decided to decertify. ${ }^{26}$

These different interpretations of the "more than ministerial aid" standard may reflect the fact that the Board's aims can vary. The Board sometimes seems to be primarily concerned with how the employer's actions affected employees in the decertification process. At other times the Board is apparently concerned with punishing employer misconduct, even if that conduct was ineffectual. ${ }^{27}$ Even when the Board uses the same phrasing, however, it does not clearly define its use of the standard in that case; rather,

${ }^{23}$ Consolidated Rebuilders, Inc, 171 NLRB 1415, 1417 (1968) (creating "more than ministerial aid" standard used in many, but not all, subsequent NLRB and court decisions). The same standard has been used, for example, in Vic Koenig Cheurolet, Inc, 321 NLRB 1255, 1258 (1996), revd, 126 F3d 947 (7th Cir 1997); Ermst Home Centers, 308 NLRB 848, 848 (1992); Pic Way Shoe Mart, 308 NLRB 84, 84 (1992); Eastern States Optical Co, 275 NLRB 371, 372 (1985); Times-Herald, Inc, 253 NLRB 524, 524 (1980).

24 Peirce, 31 Buff I Rev at 749 (cited in note 12), citing Dayton Blueprint, 193 NLRB 1100, 1108 (1971), and Placke Toyota, Inc, 215 NLRB 395, 395 (1974).

25203 NLRB 370 (1973).

${ }^{26}$ Id at 377 (ALJ "would hesitate to find Respondent guilty of statutorily forbidden 'assistance' merely because the firm's top supervisor had 'accommodated' some of his subordinates by providing them with transportation," after the decision to seek decertification had been made.).

${ }^{27}$ Compare, for example, KONO-TV-Mission Telecasting Corp, 163 NLRB 1005, 1006 (1967) (finding that employer had not violated Section $8(a)(1)$ because its actions did not have the effect of infringing on the employees' exercise of their Section 7 rights), with The Hearst Corp, 281 NLRB 764, 765 (1986) (punishing employer for actions of which the majority of employees was unaware, and noting that " $[t]$ he finding of a violation is not predicated on a finding of actual coercive effect, but rather on the tendency of such conduct to interfere with the free exercise of employee rights under the Act"') (citation omitted). 
the Board fits its fact-specific determinations into an ambiguous standard, resulting in a standard that does not aid employers in determining if their actions will violate the law.

\section{B. Judicial Criticism of the Board's Standard (or Lack Thereof)}

In the most recent appeals court case to address employer assistance in decertification, Vic Koenig Chevrolet, Inc $v N L R B,{ }^{28}$ the Seventh Circuit expressed its frustration with the state of Board decisions on this issue, disagreeing with the Board's finding that the employer had interfered with its employees' free choice. ${ }^{29}$ In reviewing the Board's decision for reasonableness, the court objected that the Board

expressly endorsed the 'no more than ministerial aid' formula, ... but failed to indicate whether the formula means anything more than that the employer may not give aid that is likely to affect the outcome of the decertification effort. The Board . . . had seemed to define 'ministerial aid' as aid not likely to affect the outcome. . . . But elsewhere the opinion ... discusses the 'ministerial aid' formula as if its interpretation stood free from any reference to the objective of protecting the free choice of the employees, in much the same way that the Miranda rule stands free from its underlying objective of preventing coerced confessions. ${ }^{30}$

The court concluded that because the Board did not explicitly adopt a definition of "more than ministerial aid," its decision should not be reviewed for substantial evidence that Koenig supplied more than ministerial aid, but instead should be reviewed for consistency with Section 7's "unquestioned standard" that the employer may not interfere with free choice. ${ }^{31}$ Given an undefined and ambiguous standard by the NLRB, the Seventh Circuit retreated to the language of the NLRA, asking not whether the NLRB was correct that Koenig supplied more than ministerial aid, but instead whether the NLRB was correct in its underlying

\footnotetext{
${ }^{28} 126$ F3d 947 (7th Cir 1997).

29 Id at 947.

${ }^{30}$ Id at 949.

${ }^{31}$ Id at 950. Courts review NLRB interpretations of the NLRA for reasonableness and determinations of fact for the support of "substantial evidence" in the record as a whole. See Cheuron, USA v Natural Resources Defense Council, 467 US 837, 866 (1984); Universal Camera Corp v NLRB, 340 US 474, 477 (1951). The Administrative Procedure Act generally requires a standard of "reasoned decisionmaking" in adjudication: the agency's decision must be "within the scope of its lawful authority," and the "process by which it reaches that result must be logical and rational." Allentown Mack Sales and Service, Inc $v$ $N L R B, 522$ US $359,118 \mathrm{~S}$ Ct 818,826 (1998).
} 
assertion that Koenig's assistance interfered with his employees' free choice.

The facts of Koenig illustrate why not having a coherent standard presents problems for employers and employees. In Koenig, employees chose first to vote to initiate a decertification petition and then to vote again by signing individual petitions. Both votes resulted in 7 to 4 decisions against the union. After the votes, the employer (Koenig) told the mechanic conducting the effort that his lawyer had advised him that the petitions had been incorrectly worded: while the vote was conducted on the question, "Do you wish to remain in the union?," the individual petitions indicated that the "undersigned wish to withdraw our membership from" the union. According to Koenig's lawyer, the petitions should instead have stated that the employees no longer wanted the union to represent them. The change was made, new petitions were drawn up, and, not surprisingly, the result was the same. ${ }^{32}$ All three actions occurred on the same day. Based on the final set of petitions, Koenig immediately withdrew his recognition of the union. ${ }^{33}$

As the Seventh Circuit's decision points out, the only way in which the change in wording could have affected the petition results was if one or more of the employees wanted to withdraw as a member of the union but nevertheless wanted the union to continue representing him or her. Yet an employee does not vote with a group to withdraw from the union; withdrawal is an individual right. ${ }^{34}$ Nevertheless, the NLRB concluded that Koenig's assistance had "tainted" the last vote. According to the Board, the

\footnotetext{
"During the second petition vote, one of the employees was not present, resulting in a 6 to 4 vote. Koenig, 126 F3d at 950-51.

${ }^{35}$ In Koenig, there was a collective bargaining agreement in effect, so the employees' decertification effort was barred, but the vote could be used by the employer to withdraw recognition and refuse to negotiate future contracts with the union. Id. See also note 5 .

${ }^{*}$ Id at 952 . Sections $8(a)(3)$ and $8(b)(2)$ prohibit agreements that require employees to be formal union members (union and closed shops). 29 USC $\S 158$. See also NLRB v Hershey Foods Corp, 513 F2d 1083, 1084-85 (9th Cir 1975) (establishing that union shop contracts cannot require full-fledged membership but only the payment of dues and initiation fees, allowing employees to treat the agreement as if it created an agency shop). Employees may therefore withdraw from the union as individuals. They may, however, still be obligated to pay the union the costs it incurs in representing them, since (typically) until the majority of the bargaining unit votes to decertify a union, it remains the representative of everyone in the bargaining unit, both members and nonmembers alike. Communication Workers $v$ Beck, 487 US 735, 745-49 (1988); Wegscheid v Local Union, 117 F3d 986, 987 (7th Cir 1997). State laws may prohibit all such "union security agreements." 29 USC $\$ 164(\mathrm{~b})$. In the NLRA, as the Supreme Court has said, "membership is whittled down to its financial core." NLRB v General Motors Corp, 373 US 734, 742 (1963) (upholding an agency shop contract requiring employees to pay dues and initiation fees regardless of whether they join).
} 
very fact that the labor lawyer suggested the rewording proved that Koenig did not have an objective basis for withdrawing recognition before he rendered the "assistance." Thus, the Board found that Koenig's withdrawal of recognition was unfounded because the provision of his attorney's advice was not simple ministerial aid to employees who had already decided to petition for decertification but instead was interference with the employees' decision. ${ }^{35}$

The Seventh Circuit held the Board's inference to be "completely unreasonable." authoritatively define its "no more than ministerial assistance" standard either as a strict rule barring "all nontrivial assistance whenever rendered," or as a simple effects-based rule prohibiting any "aid that is likely to affect the outcome of the decertification effort." The court claimed that the Board "flirt[ed] with" the strict standard in its Koenig decision, yet did not "purport to adopt it, attempt to square it with the Board's previous decisions, or offer a justification for it." ${ }^{\text {s8 }}$ Because the Board had not provided a definition of "more than ministerial aid," the court reviewed the Board's decision, looking for any impact the assistance might have had on the employees' Section 7 rights. ${ }^{39}$

\section{Lack of Clarity Provided by Board Decisions}

Given a list of circumstances in which the Board has found a violation, and one in which it has not, disagreements like the one between the NLRB and the Seventh Circuit about whether Koenig provided mere ministerial aid are hardly surprising. Compounding the vagueness of the "more than ministerial aid" standard is the fact that the cases brought to the NLRB involve various factual scenarios and contexts. These differences in prior cases make it difficult for the ALJs, the NLRB, and the courts to determine whether an employer in a given case has violated the NLRA by providing "more than ministerial aid" to its employees in their decertification efforts.

In part, this difficulty arises because most cases involve more than one challenged incident of assistance, making it hard to identify exactly what types of assistance the Board or courts consider ministerial. ${ }^{40}$ For example, the forms of assistance at issue

\footnotetext{
${ }^{35}$ Koenig, 321 NLRB at 1260.

${ }^{36}$ Koenig, 126 F3d at 952.

${ }^{37}$ Id at 949-50.

${ }^{38}$ Id at 950.

so Id.

${ }^{40}$ There is no suggestion that the Board's changing terminology reflects a substantive
} 
in Koenig-typing, xeroxing, advice on wording the petition, and providing an attorney to count the petitions-are relatively common. But the decisions do not definitively indicate whether the NLRA allows or prohibits any individual type of assistance. Consider, for example, an employer who helps employees process their petition by getting signatures, typing the petition, and other similar acts. In one NRLB case, Dayton Blueprint Co ${ }^{41}$ the Board held that an employer violated Section 8(a)(1) when it responded to the employees' request by typing the decertification petition and allowing the petitioning employees to file the petition on company time and to use the company car to deliver the petition (though it is not clear that the use of the car was approved in advance). ${ }^{42}$ In Washington Street Brass \& Iron Foundry, Inc, ${ }^{43}$ by contrast, the Board did not find an NLRA violation when an employer's agent suggested changes to the wording of the decertification petition and gave the employees, at their request, a ride to the Board office. ${ }^{44}$ In each case, the Board's decision seems ultimately based on the employer's overall conduct and not individual acts, so the decisions do not help a subsequent employer who wants to know about the permissibility of a particular action.

Context also explains some of the difficulty. The general rule is that even mere ministerial aid in decertification is unlawful when it occurs in the context of other unfair labor practices: ${ }^{45} \mathrm{em}$ ployees may infer antiunion animus from the employer's actions unrelated to decertification. Evidence of unfair labor practices may color the Board's interpretation of even the most trivial assistance. Given this concern with employee perceptions, it would seem intuitive that even a context of antiunion bias that does not amount to an unfair labor practice should produce decisions

change in the standard of permitted employer conduct, so cases decided under alternative terminology (that is, those that do not enunciate the "more than ministerial aid" standard) may be considered in analyzing "ministerial aid."

193 NLRB 1100 (1971).

42 Id at 1107-08.

268 NLRB 338 (1983).

4 Id at 338-39.

ts See, for example, Royal Himmel Distilling Co, 203 NLRB at 377 (noting that while providing transportation might itself be innocuous, it had to be considered in the context of other Section 8(a)(1) violations, as "part and parcel of [the employer's] statutorily proscribed program or plan"). See also The Hearst Corp, 281 NLRB at 764-65 (finding unfair labor practices of which most employees were unaware sufficient to keep the employer from relying on what was probably a legitimate decertification petition to withdraw recognition). Note, too, that the NLRB will normally not hold a decertification election if there are pending charges of unfair labor practices that would interfere with the employees' free choice in the election-these are known as "blocking charges." Michael C. Harper and Samuel Estreicher, Labor Law: Cases, Materials, and Problems 310 (Little, Brown 4th ed 1996). 
against the employer. But the Board's decisions in such cases have not always adhered to this principle. In GAF Corp,${ }^{46}$ prior to decertification the employer had made unlawful antiunion suggestions and provided (unsolicited) an employee the section of the collective bargaining agreement about revoking checkoff authorizations; nevertheless, the Board held that the employer did not violate the NLRA when it simply provided accurate information regarding the mechanics of decertification to inquiring employees and provided wording for the caption of the decertification petition. ${ }^{47}$ And in Times-Herald, Inc ${ }^{48}$ the Board found the employer had not violated Section 8(a)(1) even though a supervisor who was hired as a striker replacement initiated and solicited employee support for the decertification petition through his position's technical status as a unit member (though he himself had never joined the union); the employer also provided the Board's phone number and described the decertification process. ${ }^{49}$ Finally, in another case an employer who (1) issued a memorandum indicating he would preserve the status quo and employees would benefit if they would decertify the union, then (2) provided the language for the petition, and (3) gave the employees information necessary to complete the form, did not violate the NLRA but provided "mere ministerial aid to one who had decided of her own volition to file a decertification petition. ${ }^{30}$

By contrast, at times the Board has found violations of the ministerial aid standard using what appears to be a prophylactic rationale in cases where the employees were probably unaware of the employer's antiunion animus. In Central Washington Hospi$t a l,{ }^{51}$ because the employer had earlier suggested decertification to complaining (not inquiring) employees who took no action, the Board held that the employer violated Section 8(a)(1) simply by answering another employee's questions, approving the wording she devised, allowing her to circulate the petition on company time, and giving her access to xerox and mailing facilities. ${ }^{52}$ The Board conceded that "[m]inisterial acts by an employer that help employees in processing a decertification petition do not necessarily violate the Act," ${ }^{13}$ and that the effect of the employer's ear-

\footnotetext{
195 NLRB 169 (1972).

47 Id at 169.

253 NLRB 524 (1980).

49 Id at 526.

${ }^{50}$ Ernst Home Centers, 308 NLRB at 848.

s1 279 NLRB 60 (1986).

${ }^{52}$ Id at 64 .

$\infty$ Id at 68 .
} 
lier suggestion was not to instigate the decertification process. Nonetheless, it found that because the employer wanted to instigate the process, its other related actions that might be excusable in other cases were not excusable here. ${ }^{54}$ The Hearst Corp $p^{55}$ illustrates a similar rationale. There, the employer did not actually assist in the decertification effort, yet the Board forbade the employer from withdrawing recognition based on the employees' petition because the employer had promised benefits and engaged in other unfair labor practices with respect to a few employees. Although most of the employees signing the petition in this case knew nothing of the employer's misconduct, and decertification probably did represent the employees' will, the Board held the employer to the "foreseeable consequences" of its actions to undermine the union with respect to those few employees:.5 "The finding of a violation is not predicated on a finding of actual coercive effect, but rather on the tendency of such conduct to interfere with the free exercise of employee rights under the Act."

Sometimes, however, the divergent outcomes cannot be explained by the concern about antiunion bias. Even when an employer has not demonstrated hostility toward the union, he may not be able to tell which individual actions he can safely take. For example, in Condon Transport, Inc, ${ }^{58}$ the Board found that an employer who responded to employee inquiries by explaining the decertification process, procuring a Board petition form, and providing information necessary to complete the form had "enmesh[ed] itself" in the process sufficiently to violate the NLRA. ${ }^{59}$ This result contrasts sharply with the Board's earlier finding that the GAF Corporation's similar actions in the context of obvious antiunion bias were permissible and with the Board's holding that that the employer in Eastern States Optical $\mathrm{Co}^{60}$ did not violate the NLRA although its attorney approved (and may have provided) the wording for the decertification petition and provided information necessary to complete the form. ${ }^{61}$ Further, in Placke Toyota, ${ }^{62}$ the Board held that the employer violated the NLRA where a shop foreman granted an employee's request to have a secretary type the handwritten petition (which she did on

st Id.

ss 281 NLRB 764 (1986).

Id at 764-65.

"Id at 765, quoting Amason, Inc, 269 NLRB 750, 750 n 2 (1984).

${ }^{58} 211$ NLRB 297 (1974).

3 Id at 302.

${ }^{\infty} 275$ NLRB 371 (1985).

"Id at 372.

215 NLRB 395 (1974). 
company letterhead) and then allowed the petition to remain on his "order" desk for signatures. ${ }^{63}$ And an employer who made the mistake of contacting a labor consultant and asking the consultant to call an employee who wanted advice about getting rid of the union, "rather than merely giv[ing the employee] Labor Consultant Ricker's name and telephone number," was held by the Board to have violated Section 8(a)(1) of the Act, even though the ALJ had found only ministerial aid. ${ }^{64}$ Similar disagreements arose in both GAF Corp and Eastern States, where the ALJs found violations that the Board, looking at the same facts anew, overturned. This inability to agree on the evaluation of the same facts further underscores the uncertainty that the Board's current "standard" engenders.

\section{Costs of Uncertainty}

Some broad lines can be drawn from the above examples, but they leave intact the problem plaguing the decisions-the definition of "ministerial" or "trivial." There is a substantial gray area of forms of assistance that the Board has approved in some contexts and in some combinations and held to violate the Act in others. The resulting uncertainty is costly to all the participants.

One could argue, of course, that this uncertainty properly chills employer involvement by making employers more cautious about trying to influence or persuade employees to decertify their union. Much of the assistance that employers provide could probably be obtained by employees elsewhere, so that discouraging employers might not measurably limit the employees' exercise of their freedom of choice. Finally, it could also prevent employers from "loopholing," avoiding those types of behavior the NLRB might list as forbidden while nonetheless interfering with the employees' free choice.

Section 8(a)(1), though, protects employees against true employer interference. Any chilling effect resulting from uncertainty about the ministerial aid standard instead works to thwart the exercise of employees' Section 7 rights, since the employer is the most logical source of assistance when, as here, employees cannot turn to their union representatives.

Employers bear the costs of this uncertainty most directly. Even when their actions are not challenged by the union, employers must incur the costs of seeking legal advice in order to ensure that they comply with the Board's murky standard. Employees

cs Id at 395-96.

4 Pic Way Shoe Mart, 308 NLRB at 84. 
also lose. First, they may have difficulty getting the neutral information that could help them make their decision to decertify. Unless it were extremely strict, a clearer definition of "ministerial aid" would likely allow employers to provide several forms of aid that employees request routinely and employers now refuse because of the uncertain legal standard. For example, under a clear standard, it might be possible for employers to provide employees the information necessary to complete the petition, assist in wording the petition, or allow employees to circulate the petition at work. None of these acts, alone or in combination, can be said to interfere with the employees' freedom of choice and, in fact, seem to further such choice. Second, employees bear the costs of the delay the uncertainty frequently causes; rather than decertifying the union and selecting a new (or no) representative, employees often go without effective representation (and pay dues to the incumbent union) while the union objects to employer assistance, the Board adjudicates, and a rerun election is held. Third, and less obviously, uncertainty harms the employer-employee relationship by making it more adversarial. The employer's desire not to run afoul of the "ministerial aid" standard, coupled with uncertainty about the standard, may cause the employer to refuse to provide some forms of assistance that seem, in common usage of the words, to be "merely ministerial"; 65 this behavior may seem to employees to be unnecessarily conservative. One commentator suggests, for example, that while employers may suggest to inquiring employees that they call the NLRB, they would be "ill-advised" to give them the Board phone number. ${ }^{66}$ Few employees will see this apparently arbitrary distinction as a clear legal line between ministerial aid and unlawful interference; instead they may suspect their employer's motives and will probably see it as frustrating their legitimate requests.

Finally, the uncertainty imposes costs on the NLRB. Most significantly, the Board bears the cost of ordering and conducting the rerun elections that are held when the employer's actions do not rise to an unfair labor practice but do disturb sufficiently the "laboratory conditions" of the election so that the initial election

* Commentators have noted in passing this negative policy implication of uncertainty that the Board's standard creates. See, for example, Krupman and Rasin, 30 Labor L J at 233-34 (cited in note 12).

* Peirce, 31 Buff L Rev at 794 (cited in note 12).

or General Shoe Corp, 77 NLRB 124, 127 (1948). Of the 485 elections held in 1996, the union objected in fifteen cases (employers objected to union actions in five cases), and thirteen rerun elections were held. Sixty-First Annual Report at Tables 11, 11A, 11C (cited in note 10). These remun elections reversed the initial outcome 40 percent of the time. Id at Table 11E. Granted, in absolute terms these are not large numbers. But each objection 
is set aside. The Board also incurs costs by having a standard that results in many exceptions to and occasional reversals of ALJ decisions. Finally, one could argue that this lack of a clear standard limits the NLRA's effectiveness in guiding behavior.

In sum, if employers and unions knew what types of conduct were per se forbidden and per se allowed, the Board would spend less time and fewer resources hearing objections and conducting second and third elections; employers would spend less time and money in front of the Board; and employees would achieve the results they seek-usually decertification-much more quickly, thereby saving the cost of additional dues and allowing selection of a new union in the interim.

\section{PROPOSED INTERPRETATIONS FOR A MORE CERTAIN STANDARD}

The Board and court decisions on this issue have suggested and employed several theoretical lines between the permissible and impermissible forms of assistance. Some have the advantage of mimicking the NLRA's language, others of creating a brightline rule for when assistance is permissible, and still others of ending the issue altogether by prohibiting assistance completely. Each theory, however, presents corresponding disadvantages, some practical and others constitutional. This Part will examine the advantages and disadvantages of (1) an effects-based inquiry, (2) a prophylactic rule, (3) a timing-based rule, and (4) two variations of a rule prohibiting all "nontrivial assistance whenever rendered." 68

Ultimately this Comment concludes that labor policy would be best served by a rule that would prohibit nontrivial assistance regardless of its timing or effects but define nontrivial relatively broadly. In addition, this Comment recommends that the Board and courts establish a prospective categorization of various forms of assistance as trivial or nontrivial. Because the NLRB is reluctant to use its express rulemaking authority ${ }^{69}$ the Board and reviewing courts should, in their future decisions, separately classify each form of assistance provided by the employer as trivial or nontrivial and develop a standard for determining how much trivial assistance may be provided before it crosses the threshold and becomes nontrivial.

filed and each rerun election conducted consumes significant resources.

${ }^{8}$ Koenig, 126 F3d at 950.

( See note 20. 


\section{A. Effects-Based Inquiry}

The effects-based test interprets "ministerial aid" to give employers the right to "provide the workers with any assistance that doesn't interfere with their freedom of choice." The Seventh Circuit in Koenig suggested that this is "the standard implied by sections 7 and 8 of the Act," ${ }^{, 1}$ and one NLRB member, dissenting from the Board's decision in Koenig, similarly concluded that "[u]ltimately, the issue is whether the employer interfered with employee rights guaranteed by the Act." ${ }^{m 2}$ Thus, a standard that focuses on employee freedom of choice would promote the NLRA's purpose as expressed in Section 7.

Of the proposed interpretations of "ministerial aid," the effects-based inquiry is probably the most frequently used in the decisions. Moreover, it most closely relates to the rationale for the standard, the employees' Section 7 rights. ${ }^{73}$ If decertification exists in order to ensure that employees are exercising their free choice regarding union representation, the Board ought to focus on how the employer's actions affect that free choice and not whether the aid may be defined as "ministerial" or not. The effects-based interpretation thus has the initial advantages of precedent and common sense.

On the other hand, the Board and reviewing courts incur significant decision costs when they use an effects-based inquiry because they must consider not only the objective facts, such as what the employer did, but also the employees' subjective perception of how the employer's actions influenced their free choice. The more information necessary to make a decision and the more subjective that information, the less likely it is that the Board or any decisionmaker will make the correct decision. These disadvantages probably outweigh the initial appeal of an interpretation that seems facially to force the Board to adhere to Section 7, but that in fact, because of the case-by-case examination procedures, allows the Board wide latitude for both error and caprice.

\footnotetext{
7o Koenig, 126 F3d at 949.

"Id. The court noted that the NLRB has explicitly used this standard at times (see, for example, Washington Street Brass \& Iron Foundary, 268 NLRB at 339), on the premise that Sections 7 and 8, employee freedom of choice and employer noninterference, define the limits of allowable assistance.

${ }^{72} 321$ NLRB at 1263 (Member Cohen dissenting).

73 See note 3. The point of Sections 7 and 8 is to ensure that employees are free to choose or not to choose union representation; employer actions, whatever their intent, that have no effect on the exercise of that choice would therefore be irrelevant.
} 
B. Prophylactic Rule

At the other extreme, the most obvious solution to the uncertainty problem is a bright-line approach occasionally used by the Board: ${ }^{74}$ forbid employers from assisting their employees beyond directing them to the NLRB, regardless of whether the employer's actions influence the employees or the employees know of the employer's actions. If the Board finds any additional assistance by the employer (whenever rendered), it will disallow the employer's withdrawal of recognition, invalidate the employees' decertification petition, and/or rerun any decertification election. The prophylactic rule overlaps significantly with the stricter of the two "nontrivial assistance" standards that are discussed below. They differ, however, in that under the prophylactic rule the employees' knowledge of the employer's conduct is irrelevant. The prophylactic rule focuses on the employer's conduct and incentives and chills even those surreptitious forms of assistance about which the employees may know nothing, on the understanding that Section 7 requires employers to stay completely out of the employees' choice of representation.

If one adopts a cynical view of all assistance employers render to employees involved in a decertification campaign and assumes that employees will, if uncoerced, choose to remain in their unions, the prophylactic rule would be not only predictable, but also accurate. This perspective corresponds to the understanding of the NLRA's drafters, who mandated that a union buffer be available between employer and employee as a way of protecting powerless employees from exploitative employers. For example, Section 1 of the NLRA states its purpose: to rectify "[t]he inequality of bargaining power between employees who do not possess full freedom of association or actual liberty of contract, and employers who are organized." ${ }^{25}$ Similarly, provisions such as Section 8(a)(2)'s "company union" prohibition ${ }^{76}$ rely on the

${ }^{74}$ Apparent examples of the prophylactic approach may be seen in Hearst Corp, 281 NLRB at 764-65 (finding that the existence of labor violations, of which only some employees were aware, tainted the vote); Koenig, 321 NLRB at 1260 (finding that the employer's suggested rewording of the petition tainted the vote); Pic Way Shoe Mart, 308 NLRB 84, 84 (1992) (finding that the employer violated the Act by calling the NLRB rather than giving the employee the number).

${ }^{75} 29$ USC \& 151.

${ }^{78}$ Section 8(a)(2) provides that it shall be an unfair labor practice for an employer "to dominate or interfere with the formation or administration of any labor organization or contribute financial or other support to it." 29 USC $\S 158(a)(2)$. This provision has been deemed to preclude cooperative arrangements, like "employee action committees," which touch on terms or conditions of employment. See, for example, Electromation, Inc, 309 NLRB 990, 990 (1992), affd, 35 F3d 1148 (7th Cir 1994). 
NLRA's assumption 'that workers, if given freedom of choice, would resoundingly prefer representation by independent unions. ... [Section 8(a)(2)] could be viewed as corresponding to, and helping to effectuate, the underlying desires of the affected workers." $\$ 77$

However, this view of labor relations may not be suited to today's workplace; many labor law commentators opine that the adversarial model of the workplace reflected in the NLRA is outmoded and that the NLRA's reliance on it in fact restricts progress in working conditions and productivity. ${ }^{78}$ Similarly, it seems anachronistic to continue to presume that any and all assistance employers give employees who seek to decertify their unions comes from the employer's' ultimate desire to exploit soon-to-bepowerless employees. Doubtless, antiunion animus motivates employer assistance in many cases, ${ }^{79}$ particularly where the employer initially suggests the process, ${ }^{80}$ but much more often em-

7 Estreicher, 69 NYU L Rev at 133 (cited in note 6).

7s One commentator has argued that the NLRA as a whole is no longer enlarging employee power to deal with the employer and to improve living conditions and that we need legislative action to improve its operations. Joan E. Baker, NLRA Section 8(a)(3) and the Search for a National Labor Policy, 7 Hofstra Labor I J 71, 72 (1989) ("The legislative proposals [outlined here] . . . suggest that sweeping changes be made to existing labor legislation by requiring fundamental . . redefinition of national labor policy."). For examples that use the same theme to criticize, and suggest reforms of, Section $8(a)(2)$ specifically, see Estreicher, 69 NYU L Rev at 125 (cited in note 6) (arguing for the repeal of Section $8(a)(2)$ except as it outlaws the deceptive installation of employer-dominated organizations to represent employees collectively); Sharon G. Clarke, Rethinking the Adversarial Model in Labor Relations: An Argument for a Repeal of Section 8(a)(2), 96 Yale I J 2021, 2021 (1987) (arguing that Congress should implement a system whereby groups of workers could choose between cooperative and adversarial models). See also Mark Barenberg, Democracy and Domination in the Law of Workplace Cooperation: From Bureaucratic to Flexible Production, 94 Colum L Rev 753, 946-47 (1994) (suggesting a new policy interpretation of Section $8(\mathrm{a})(2)$ based on standards of nondomination).

"See, for example, NLRB v Sky Wolf Sales, 470 F2d 827, 828-30 (9th Cir 1972); Hearst Corp, 281 NLRB at 782; Weisser Optical Co, 274 NLRB 961, 961 (1985) ("The record reveals that . . . in early 1983, the Respondent's owner . . . asked [an] employee to initiate a decertification effort, explaining that he wanted to rid the Respondent of the Union. [Employee] reluctantly agreed, and was provided a booklet explaining the Board's decertification process."); Cummins Component Plant, 259 NLRB 456, 456-57 (1981); Craftool Manufacturing Co, 229 NLRB 634, 636-37 (1977); Allou Distributors, Inc, 201 NLRB 47, 52-53 (1973) (The employer, who stated that "he would rather go out of business than accept some of the Union's demands," prepared a decertification petition for his employees.).

${ }^{*}$ Interestingly, these are often cases that the prophylactic rule reaches but that the strict interpretation of a ban on all nontrivial assistance (see below) might not-such as when the illicit suggestion is made to employees who have no role in the eventual decertification effort. See, for example, Hearst Corp, 281 NLRB at 765; Central Washington Hospital, 279 NLRB at 64-65. As a general rule, the Board's policy prohibiting employers from suggesting decertification to complaining employees might be criticized as counterproductive when one considers that many employees are not aware of the option. A better solution than allowing employer suggestion, though, is for the NLRB to require that employers 
ployer assistance results from an employee inquiry or request ${ }^{81}$ or is offered after the decertification petition process is well underway. ${ }^{82}$ In many cases the very context of the assistance exemplifies the cooperative relationship between the employer and the employees that many commentators argue the NLRA detrimentally discourages. The possibility remains, of course, that the employer's assistance-however innocent-might still influence the outcome of an election, if one eventually occurs. But the possibility of influencing an election "would still be some distance from interfering with free choice; choices are made on a weighing of influences. ${ }^{m 3}$ Thus, it is likely that a prophylactic rule impinges on employer behavior far beyond what is necessary to protect the employees' Section 7 rights.

The prophylactic rule may also be unconstitutional. Though the cases tend to focus on employer actions to assist decertification efforts, most also involve at least some employer speech. If antiunion speech to employees in the context of a decertification effort were considered within the scope of the prophylactic rule (as it should be, given its potential to aid or influence the decertification effort), the rule might violate the First Amendment and the concurrent free speech clause contained in Section 8(c) of the NLRA. ${ }^{84}$ A complete treatment of this important provision of the NLRA is beyond the scope of this Comment, but a brief explanation of the limits these constitutional and statutory speech protections would place on the prophylactic rule is in order.

post this information in every workplace, in order to inform employees of the decertification process. See text accompanying notes 120-21.

${ }^{81}$ See, for example, Errst Home Centers, 308 NLRB 848, 848 (1992); Pic Way Shoe Mart, 308 NLRB at 84; Eastern States, 275 NLRB at 371; Placke Toyota, 215 NLRB at 395; Dayton Blueprint Co, 193 NLRB at 1107-08.

${ }^{2}$ One of the most obvious examples of this situation is the ride the employer provided its employees to the NLRB office in Washington Street Brass \& Iron Foundry, 268 NLRB at 339, and in Royal Himmel Distilling Co, 203 NLRB at 374.

Koenig, 126 F3d at 950.

a 29 USC $\S 158(\mathrm{c})$ provides:

The expressing of any views, argument, or opinion, or the dissemination thereof, whether in written, printed, graphic, or visual form, shall not constitute or be evidence of an unfair labor practice under any of the provisions of this Act, if such expression contains no threat of reprisal or force or promise of benefit.

The Seventh Circuit mentioned the possible conflict with this provision:

And the bearing of the free-speech clause in the [NLRA] would have to be considered, though it is not argued that the clause entitles employers to engage in as it were continuous campaigning to persuade their employees to forgo collective bargaining, and it is the very core of the rule whose scope is in issue in this case that the employer may not urge his employees to seek decertification.

Koenig, 126 F3d at 950 (citations omitted). 
Section 8(c) was added to the NLRA in the 1947 Taft-Hartley Act $^{85}$ to provide greater protection for employer speech than the Board had provided and to ensure that noncoercive speech would not be construed as an unfair labor practice. In NLRB $v$ Gissel Packing $\mathrm{Co}^{86}$ the Supreme Court held that the First Amendment protects noncoercive employer speech. ${ }^{87}$ The Supreme Court views Section 8(c) as a method of implementing the First Amendment in the labor context, ${ }^{88}$ though it has construed the protection relatively narrowly in the representation context. The Board's 'laboratory conditions" doctrine, which allows the Board to set aside elections as "tainted" even though the employer's speech did not rise to the level of an unfair labor practice ${ }^{89}$ has further limited the First Amendment's impact in the context of representation elections by requiring election results to be set aside on the basis of otherwise protected speech..$^{00}$

If a prophylactic rule were interpreted as including speech within its scope, it would infringe on the employer's speech still further than current Board doctrine. The First Amendment requires that restrictions on speech be narrowly drawn..$^{91}$ Even considering the entire decertification process (petition, waiting, and

os Labor Management Relations Act, 1947, Pub L No 101, 61 Stat 135, 140, codified at 29 USC $\S 158(\mathrm{c})$ (1994). Section 8(c) reiterates the Supreme Court's holding in NLRB $v$ Virginia Electric \& Power Co, 314 US 469 (1941) (holding that the NLRA does not forbid employers from expressing their views on unions).

so 395 US 575 (1969).

${ }^{87}$ Id at 617 . The Gissel standard allows noncoercive speech, including only those predictions about the economic consequences of unionization that are based on objective facts and not within the employer's control. See also Thomas $v$ Collins, 323 US 516, 537-38 (1945) (recognizing that employers' attempts to convince employees to join, or not join, unions are "within the First Amendment's guaranty").

The Board has held that Section $8(\mathrm{c})$ is not applicable in representation cases but that the First Amendment is. Dal-Tex Optical Co, 137 NLRB 1782 (1962).

so The "laboratory conditions" ideal was enunciated in General Shoe Corp, 77 NLRB 124, 127 (1948).

so Both the laboratory conditions doctrine and the stringency of the Gissel standard relative to ordinary First Amendment analysis have been widely criticized. See, for example, Cynthia Milne, New Freedom for Employer Communications, 3 Hofstra Labor L J 235, 243-49 (1986) (criticizing the Board for past decisions that made employer suggestions of decertification a per se violation and applauding the Board's retreat from that position); Julius Getman, Labor Law and Free Speech: The Curious Policy of Limited Expression, 43 Md L Rev 4, 19-20 (1984) (strongly critiquing the restriction of speech rights in the labor context generally as resting on a "common, stereotyped, and paternalistic vision of workers as people whose decisions are not made on the basis of ideas and persuasion but on the basis of fear, coercion and discipline"). For the opposite perspective, see Alan Story, Employer Speech, Union Representation Elections, and the First Amendment, 16 Berkeley $J$ Emp \& Labor I 356, 381-405 (1995) (arguing that employer speech is corporate commercial speech and should be given less constitutional protection).

${ }^{91}$ Sylvia G. Eaves, Employer Free Speech During Representation Elections, 35 SC L Rev 617, 642-43 (1984). 
election) to be an election-like situation covered by the laboratory conditions doctrine, the availability of less restrictive means of ensuring noncoercive elections (such as focusing on the effects of speech) suggests that the prophylactic rule's complete prohibition of an employer's pro-decertification or antiunion speech would fail the First Amendment test. The Board's rule that the employer may not suggest decertification to its employees could survive ${ }^{92}$ if one assumes that, but for the employer's suggestion, the employees would not have decertified the union. A prophylactic rule prohibiting all employer speech once the employees have expressed their intentions in some form, however, would be constitutionally questionable.

The other, less fundamental but still significant danger of a prophylactic rule is that employees might seek assistance and unwittingly cause an employer to violate the rule, thereby defeating the exercise of their own free choice. In Dayton Blueprint $\mathrm{Co}$, for example, it was unclear if the employer knew in advance why the employees were borrowing the company car, yet the Board imputed the assistance to the employer and invalidated the petition..$^{33}$ This may be a common problem, as employees very often think nothing of using the office copier for matters at least somewhat related to work (as a decertification petition would be), circulating a decertification petition on working time, or even having a company secretary type up a short handwritten statement. Each of these actions, however, would violate a prophylactic rule; the rule would thereby impair the employees' exercise of free choice. ${ }^{94}$

"As Milne notes, though, this position contrasts with the Board's "longstanding rule that an employer can permissibly bring to the employees' attention their [analogous] right to resign from a union and to revoke their dues checkoff authorizations 'so long as the communication is free from any threat or coercion." Milne, 3 Hofstra Labor L J at 246 (cited in note 90), citing Landmark International Trucks, Inc v NLRB, 699 F2d 815, 820 (6th Cir 1983). Prohibiting employers from suggesting decertification also runs counter to the employees' free exercise of their Section 7 rights, given their probable ignorance of the option. See note 12.

s 193 NLRB at 1107-08.

* See text accompanying notes 41-44 for discussion of cases involving these and other unintentional forms of assistance. In Quinn Company, 273 NL.RB 795 (1984), for example, the employees had used company paper and typing services and circulated the petition on company time. The Board held the employer did not violate an effects-based rule because the employees acted without its knowledge. Id at 796. This same situation, however, could be held to violate a prophylactic rule if the employer did not object once it learned of the employees' use of its resources, as the lack of objection suggests approval. 
C. Timing-Based Rule

NLRB Member Cohen, dissenting from the Board's Koenig decision, ${ }^{95}$ advocated a timing-based rule: "In applying the Board's test, it is significant to ascertain whether the employer involvement comes while decertification efforts are germinating or whether the employer involvement comes after the occurrence of a free and fair expression of employee desires regarding the union. ${ }^{196}$ Given that employee free choice is the purported aim of Section 7 , he argued that an employer's assistance after employees have made their choice cannot interfere with the employees' exercise of that choice; if provided after the employee's decision, the employer's aid is therefore almost always "ministerial assistance to assure that the choice, having been freely made, is effectuated." Noting that the Board had concluded that Koenig unlawfully aided the employees by providing the proper language for the petition, an attorney to count the petitions, and clerical support, Cohen remarked, "[t]he problem with this listing of events is that they all took place after the employees freely voted to reject the Union as their representative. ${ }^{.98}$

In its simplest form, a timing-based rule would prohibit all assistance (aside from referring the employees to the Board) before the employer has evidence of an employee choice; after the choice has been made, it would allow any noncoercive assistance. The rule would provide a bright line-the employees' vote via petition to decertify - for the Board, courts, and employers to use in assessing whether assistance is allowable without being as restrictive as the prophylactic rule. Employers could communicate this black-and-white rule to employees to avoid the relationshipdamaging appearance of being unwilling to help. Of course, an employer might be uncertain as to whether or when the employees have freely chosen, ${ }^{99}$ but this ambiguity seems less likely than uncertainty about the future effects of contemplated employer assistance because the former can be determined with less subjective inquiry. The rule's biggest advantage may be that it avoids the inquiry into whether assistance is "ministerial" or "trivial" al-

\footnotetext{
* Koenig, 321 NLRB at 1263 (Member Cohen dissenting).

* Id.

rId.

*Id.

* The most obvious examples arise in cases like Koenig, where employees inexpertly drafted a petition that conveyed a desire to get rid of the union but where the NLRB felt the petition did not express a clear desire to decertify. A timing-based rule would presumably consider the employees' petition as evidence of their decision, as the Seventh Circuit did; confusion, however, could still arise.
} 
together, thereby avoiding the ambiguity inherent in this classification.

The biggest disadvantage of the rule falls on employees who seek to decertify, and thus it probably outweighs all the advantages. The timing-based rule forbids any assistance before the employees as a whole have spoken. ${ }^{100}$ It precludes most of the common forms of assistance (usually allowed by the Board ${ }^{101}$ ) that employers give to employees who instigate the decertification petition: drafting or advising on language (except in rare cases like Koenig's, where the employees had voted first on an improperly worded statement), ${ }^{102}$ providing clerical assistance, and allowing circulation of the petition on company time. Each of these forms of assistance may well be essential to the success of a particular petition; by not allowing them, the rule may prevent employees from exercising their choice to decertify their union. Under this rule, although the employer may mail petitions and provide a ride to the Board office (because the employees will have already made the decision to decertify), employee free choice will nonetheless be impeded unless the instigating employees are unusually tenacious when they first seek decertification. By making the initiation of a decertification petition and thus the exercise of Section 7 rights more difficult, the simplicity of the timing-based interpretation of "ministerial aid" proves a poor policy choice. Though it allows employers to provide assistance after the employees as a whole have decided to decertify the union, it prohibits assistance when the decertification effort may need it most.

\section{Prohibition on All "Nontrivial Assistance Whenever Rendered"103}

In Koenig, the Seventh Circuit suggested that "it would not be irrational for the Board to take the strictest view and bar all nontrivial assistance whenever rendered; the argument would be that assistance in filing the petition for decertification could conceivably influence the workers' vote in the subsequent decertification election if one were ordered." ${ }^{104}$ This proposal is susceptible

\footnotetext{
${ }^{100}$ Like the application of a prophylactic rule, this rule may run afoul of the employer free speech provision and the First Amendment. See text accompanying notes 84-92.

${ }^{102}$ See, for example, Ernst Home Centers, 308 NLRB at 848; Eastern States, 275 NLRB at 371-72; Quinn Company, 273 NLRB at 796; Washington Street Brass \& Iron Foundry, 268 NLRB at 339; Times-Herald, Inc, 253 NLRB at 524; GAF Corporation, 195 NLRB at 169.

${ }^{102}$ See also Rock-Tenn Co v NLRB, 69 F3d 803, 806 (7th Cir 1995).

${ }^{103}$ Koenig, 126 F3d at 950.

${ }^{104}$ Id.
} 
to two interpretations, one that views "nontrivial" as anything that the employees know about beyond referring employees to the NLRB ("strict") and one that classifies many ordinary forms of assistance as trivial because they are unlikely to influence employee votes ("commonsense").

The Board seems to have used this idea, with both interpretations of trivial, to interpret the "ministerial aid" standard in several cases. ${ }^{105}$ In Placke Toyota,${ }^{106}$ for example, the Board took a strict view, stating that "[a]lthough an employer does not violate the Act by referring an employee to the Board in response to a request for advice relative to removing a union as the bargaining representative, it is unlawful for him subsequently to involve himself in furthering employee efforts directed toward that very end." ${ }^{107}$ Later, in Koenig, the Board interpreted this passage more leniently, indicating that previous decisions allow an employer to provide not only necessary information for the preparation of the decertification petition ${ }^{108}$ but also the wording when requested by the employees, ${ }^{109}$ though it did not allow the employer to provide an attorney to count and verify the decertification petitions after his employees had acted. ${ }^{110}$

The critical distinction between either formulation of the "nontrivial" proposal and the effects-based inquiry"11 is that the bar on nontrivial assistance (however defined) applies not only before but after the employees have affirmatively selected decertification. In other words, the bar applies even when there is no danger of an employer interfering with employees' Section 7 rights to sign the petition and when in fact the assistance might help the employees to exercise their rights fully. In this way, it could be argued, the bar, especially under the strict interpretation, may be too restrictive, since many months intervene be-

\footnotetext{
${ }^{100}$ The Koenig decision cites, for example, Cummins Component Plant, 259 NLRB at 460-61; Times-Herald, Inc, 253 NLRB at 524; Dayton Blueprint Co, 193 NLRB at 1107-08.

${ }^{206} 215$ NLRB 395 (1974).

${ }^{100}$ Id at 395 (citations omitted).

${ }^{100}$ Koenig, 321 NLRB at 1259, citing Ernst Home Centers, 308 NLRB at 848.

${ }^{100}$ Koenig, 321 NLRB at 1259, citing Eastern States, 275 NLRB at 371 . A truly strict interpretation of "nontrivial" would probably prohibit even the provision of wording the Board allowed in Eastern States. Instead, it would probably only allow the employer to refer his employees to the NLRB, without providing a phone number or any additional information to employees, save that which they could not get on their own.

${ }^{110} \mathrm{Koenig}, 321 \mathrm{NLRB}$ at 1259.

"il Note that the categorization of acts as trivial or nontrivial will probably include an effects-based inquiry on a general level-the likely perception of an employee who knew his employer had allowed thousands of copies to be made at company expense will almost necessarily influence the Board's (or the courts') classification of such assistance as trivial or not.
} 
tween the filing of a petition and the issuance of a post-election decision. ${ }^{112}$

\section{Strict interpretation.}

A truly strict interpretation of "nontrivial" or "nonministerial" 113 would bar any and all assistance beyond (1) referring the employees to the NLRB and (2) providing the information about the company necessary to complete the form. This is essentially the prophylactic rule, except that it requires that the employees know about the assistance. ${ }^{114}$

The justifications the Koenig court provided for this rule seem to suggest that the court had a stringent interpretation of "nontrivial" in mind: any assistance, by connoting approval, might influence the workers' votes. This formulation, however, shares the drawbacks of the prophylactic rule: (1) it could damage a generally cooperative employer-employee relationship; (2) it could impede the exercise of the employees' free choice; and (3) it may infringe the employer's right to free speech. ${ }^{115}$

\section{A commonsense interpretation.}

The second, more novel interpretation views "trivial" in a more commonsense way, relying on a sort of everyday understanding that would allow the Board and courts to categorize certain forms of assistance as trivial and thus per se permissible, and other forms as nontrivial and thus per se impermissible. As is usually the case with the NLRA, the Board would be responsible for the bulk of this categorization task. The courts' involvement here would be limited to explaining how their classification differs from the NLRB's in cases where they disagree with the Board. In addition to classifying the individual forms of assistance, Board and court decisions would reach ultimate conclusions that would provide guidance in determining how many trivial acts constitute nontrivial assistance. This sort of categorization seems ideal for employers. When confronted by an employee request for aid, the employers could simply run down a list of permitted forms of aid, add up the number of times they had

\footnotetext{
${ }^{112}$ In representation cases, the Board has a median time of 267 days between the filing of a petition and the issuance of a post-election decision. See Sixty-First Annual Report at Table 23 (cited in note 10).

${ }^{113}$ Throughout this Part, the terms "trivial/nontrivial" and "ministerial/nonministerial" are used interchangeably.

${ }^{114}$ The implications of this variation of the nontrivial rule are similar to those of the prophylactic rule, discussed in Part III.B.

${ }^{115} 29$ USC \& 158(c). See also text accompanying notes 84-92.
} 
rendered trivial assistance to this decertification effort, and determine whether they could or could not legally accommodate the employees' request. (This analysis assumes that the employer has not engaged in any unfair labor practices. ${ }^{116}$ ) The Board (and reviewing courts) could create this list by expressly stating in decisions which forms of assistance, considered alone, would have been found harmlessly "ministerial" and which, either alone or in combination, would cause a violation. This process of decisionmaking would give effect to the prescription in Section 8(a)(1) that an employer not interfere with his employees' free choice, while avoiding the strict constraints on employer assistance that could limit employees in the exercise of their Section 7 right to choose not to engage in union activities.

Unfortunately, no single list can anticipate every employee request. Nor can it make the distinctions based on degree that the Board or reviewing court will make. There is, for example, a significant difference between allowing an employee to make three copies of a petition on an office copier and allowing her to make three thousand, or between providing a ride across town to the nearest NLRB office and providing a ride across the state. The uncertainty will dissipate over time, though. Order of magnitude questions will result in uncertainty and union challenges; for that very reason they will be frequently litigated in the early stages of categorization. As the categorization in the decisions progresses as more cases are decided, uncertainty about magnitude will decrease. For example, once the NLRB has deemed two hundred copies trivial and five hundred copies nontrivial, the area of uncertainty will be significantly narrowed.

Moreover, as the categorization progresses, more forms of assistance will be addressed in decisions and the decisions will provide greater guidance as to how many trivial acts constitute nontrivial assistance. The categorization cannot completely eliminate Board or judicial judgments; there will always be forms of assistance that remain unaddressed and the allowance or disallowance of certain types of assistance must be only presumptive. Even so, the enumeration would come to eliminate a significant amount of the uncertainty in this area, thereby reducing decision costs. Unlike the current standard, under which the Board considers each instance of alleged employer interference anew, this solution would obligate the Board to adhere to its earlier deci-

\footnotetext{
${ }^{118}$ The Board's usual disallowance of any assistance in the context of related unfair labor practices should remain intact, since unfair labor practices by definition interfere with employee free choice.
} 
sions, thus establishing a rule over time through adjudication rather than rulemaking. Given the NLRB's unwillingness to issue a comprehensive formal rule (which might actually be less valuable because it would be fixed in time and thereby less responsive to disputes that arise), the gradually increasing prospective certainty that categorization affords employers seems the best alternative.

This more intuitive understanding of "nontrivial" is subject to many of the criticisms raised under the strict interpretation (that is, it may bar employer assistance that will not have an impact on the employees' ability to exercise their free choice). But the commonsense interpretation blunts this criticism by acknowledging the suggestion (present both in the criticism of the NLRA's vision of employer-employee relations ${ }^{117}$ and in the Koenig court's decision ${ }^{118}$ ) that employees think more independently than the drafters of the NLRA presumed and can exercise their free choice even in the presence of significant influence by their employers. The commonsense approach would allow at any time minor forms of assistance that a timing rule would allow only after the decertification petition is underway. On the other hand, after evidence of an employee decision, the commonsense approach would continue to bar the few major forms of assistance that the timing-based rule would allow, but that would probably interfere with the employees' free choice in the later election.

Employees, it can be assumed, will presuppose that employers favor decertification. It takes little away from that presumption if the Board forbids the employer to assist in any way. By the same token, little is added to that presumption if the employer provides such "trivial" support as helping the employee word a petition, allowing employees access to the photocopying machine, providing an attorney to count the already rendered decertification petitions, or allowing employees to circulate the petition on company time. In the end, allowing "trivial," noncoercive assis-

\footnotetext{
${ }^{117}$ See note 90 for articles criticizing the NLRA's vision of employees. Professor Getman notes that the cases

manifest a common, stereotyped, and paternalistic vision of workers as people whose decisions are not made on the basis of ideas and persuasion but on the basis of fear, coercion, and discipline . . . as though the Court imagines labor relations to be a realm in which the free expression of ideas is unimportant because they are not the basis upon which actions are taken, votes cast, or picket lines observed.

Getman, $43 \mathrm{Md} L$ Rev at 19-20 (cited in note 90).

${ }^{118}$ The argument that assistance in filing the petition "could conceivably influence the workers' vote in the subsequent decertification election ... would still be some distance from interfering with free choice; choices are made on a weighing of influences." Koenig, 126 F3d at 950 .
} 
tance to employees serves as a proxy for the effects-based inquiry and comes back to the "unquestioned standard that the employer must not, by his assistance to the employees who are seeking to disconnect from the union, interfere with employee free choice."119 The categorization of nontrivial assistance simply allows certain forms of employer assistance to be presumptively valid and thus pass unchallenged by the union, lowering transaction costs for employees who opt to decertify their unions. Because the list is only presumptive and never truly "complete," the Board retains the ability to confront apparent gaming when it threatens to interfere with employee choice. By dramatically reducing employers' prospective uncertainty without fully relinquishing control, the Board will lower uncertainty costs without significantly increasing error costs.

\section{Creating employee awareness of decertification.}

Even defining "nontrivial" broadly, the Board should still prohibit employers from suggesting (unprompted) a decertification petition to an employee. The suggestion to an employee ignorant of decertification cannot be construed as "assisting" the employee in decertification because the employee is not at the time taking steps toward decertification. In fact, such a suggestion made to an employee who might be easily intimidated could be perceived as coercive, even if the employer has not otherwise revealed hostility towards the union. Thus, there must be some other mechanism to ensure that employees are aware of the existence of the decertification process. One commentator has suggested that the NLRB comprehensively inform employees of this right, ${ }_{i}^{120}$ this proposal seems to put responsibility on the leastconflicted and best-situated party. For example, a poster produced by the NLRB and required to be prominently displayed in every workplace-like the Fair Labor Standards Act and Occupational Safety and Health Act posters, which are so familiar in workplaces-would quickly solve the initial information problem without presenting the danger of unspoken employer coercion. ${ }^{121}$

"19. Id.

${ }^{120}$ Ray, 1984 Ariz St L J at 267 (cited in note 12).

${ }^{321}$ See Peter D. DeChiara, The Right to Know: An Argument for Informing Employees of Their Rights Under the National Labor Relations Act, 32 Harv J Leg 431 (1995) (suggesting a formal rule by the NLRB requiring such a poster). 


\section{CONCLUSION}

The NLRB currently uses a "ministerial aid" test to determine which forms of assistance it will permit employers to render to employee decertification efforts. Unfortunately, this test-as formulated and as applied-is too muddled to provide useful guidance to employers. A more intuitive, lenient understanding of "ministerial" would show a greater respect for the selfdetermination of employees and would likely produce both a more cooperative workplace and union-related decisions that more accurately reflect employees' free choice. The enumeration of forms of assistance as permissible or impermissible in future Board (and court) decisions, coupled with the provision by the NLRB of information on the decertification process to all employees (ideally through a standard poster in each workplace), would produce lower decision costs than the effects-based standard, provide certainty to both employer and employees, and avoid the First Amendment difficulties raised by stricter rules. 